\title{
Design and characterization of a smog chamber for studying gas-phase chemical mechanisms and aerosol formation
}

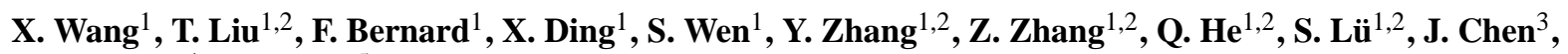 \\ S. Saunders ${ }^{4}$, and J. $\mathbf{Y u}^{5}$ \\ ${ }^{1}$ State Key Laboratory of Organic Geochemistry, Guangzhou Institute of Geochemistry, Chinese Academy of Sciences, \\ Guangzhou 510640, China \\ ${ }^{2}$ University of Chinese Academy of Sciences, Beijing 100049, China \\ ${ }^{3}$ Shanghai Key Laboratory of Atmospheric Particle Pollution and Prevention (LAP ${ }^{3}$ ), Department of Environmental Science \\ \& Engineering, Fudan University, Shanghai 200433, China \\ ${ }^{4}$ School of Chemistry and Biochemistry, The University of Western Australia, Crawley WA 6009, Australia \\ ${ }^{5}$ Department of Chemistry, Hong Kong University of Science and Technology, Kowloon, Hong Kong, China
}

Correspondence to: X. Wang (wangxm@gig.ac.cn)

Received: 3 July 2013 - Published in Atmos. Meas. Tech. Discuss.: 23 August 2013

Revised: 12 December 2013 - Accepted: 16 December 2013 - Published: 29 January 2014

\begin{abstract}
We describe here characterization of a new stateof-the-art smog chamber facility for studying atmospheric gas-phase and aerosol chemistry. The chamber consists of a $30 \mathrm{~m}^{3}$ fluorinated ethylene propylene (FEP) Teflon film reactor housed in a temperature-controlled enclosure equipped with black lamps as the light source. Temperature can be set in the range from -10 to $40^{\circ} \mathrm{C}$ at accuracy of $\pm 1{ }^{\circ} \mathrm{C}$ as measured by eight temperature sensors inside the enclosure and one just inside the reactor. Matrix air can be purified with non-methane hydrocarbons (NMHCs) $<0.5 \mathrm{ppb}$, $\mathrm{NO}_{\mathrm{x}} / \mathrm{O}_{3} /$ carbonyls $<1 \mathrm{ppb}$ and particles $<1 \mathrm{~cm}^{-3}$. The photolysis rate of $\mathrm{NO}_{2}$ is adjustable between 0 and $0.49 \mathrm{~min}^{-1}$. At $298 \mathrm{~K}$ under dry conditions, the average wall loss rates of $\mathrm{NO}, \mathrm{NO}_{2}$ and $\mathrm{O}_{3}$ were measured to be $1.41 \times 10^{-4} \mathrm{~min}^{-1}$, $1.39 \times 10^{-4} \mathrm{~min}^{-1}$ and $1.31 \times 10^{-4} \mathrm{~min}^{-1}$, respectively, and the particle number wall loss rate was measured to be $0.17 \mathrm{~h}^{-1}$. Auxiliary mechanisms of this chamber are determined and included in the Master Chemical Mechanism to evaluate and model propene- $\mathrm{NO}_{\mathrm{x}}$-air irradiation experiments. The results indicate that this new smog chamber can provide high-quality data for mechanism evaluation. Results of $\alpha$-pinene dark ozonolysis experiments revealed secondary organic aerosol (SOA) yields comparable to those from other chamber studies, and the two-product model gives a good fit for the yield data obtained in this work. Characterization experiments demonstrate that our Guangzhou Institute
\end{abstract}

of Geochemistry, Chinese Academy Sciences (GIG-CAS), smog chamber facility can be used to provide valuable data for gas-phase chemistry and secondary aerosol formation.

\section{Introduction}

Smog chambers provide a controlled environment to study the formation and the evolution of specific compounds of interest by isolating the influence of emissions, meteorology and mixing effects. Smog chambers were initially constructed for developing and evaluating atmospheric gasphase chemical mechanisms or models for predicting secondary pollutants (Akimoto et al., 1979; Carter et al., 1982; Jeffries et al., 1982, 1985). In the mid-1980s, Seinfeld and colleagues at the California Institute of Technology in Pasadena developed a $65 \mathrm{~m}^{3}$ outdoor chamber made of fluorinated ethylene propylene (FEP) Teflon film to study the aerosol formation from gas-phase precursors such as aromatic and biogenic hydrocarbons (Leone et al., 1985; Stern et al., 1987). In the subsequent three decades, outdoor and indoor chambers have been widely used to study formation of secondary pollutants such as ozone (Hess et al., 1992; Simonaitis et al., 1997; Carter, 2000; Dodge, 2000) and secondary organic aerosols (SOA) (Odum et al., 1996, 1997; Griffin et al., 1999; Martín-Reviejo and Wirtz, 2005; 
Paulsen et al., 2005; Rollins et al., 2009) and evolution of SOA (Donahue et al., 2012). Although the aims of these smog chambers are similar, their designs and capacities vary widely, displaying larger differences in factors such as sizes, reactor wall materials and light sources.

Outdoor chambers are unique in the availability of natural sunlight. Many simulation experiments on SOA formation have been carried out in large outdoor chambers (Leone et al., 1985; Stern et al., 1987; Pandis et al., 1991; Johnson et al., 2004; Martín-Reviejo and Wirtz, 2005; Rollins et al., 2009). However, diurnal variations of the actinic flux and temperature make it difficult to model experimental data and to reproduce the experiments. Indoor chambers instead can provide precise control of temperature and humidity, but may suffer from the difference between the artificial light spectrum and solar spectrum, resulting in different rates of some photolysis reactions between the artificial and natural systems (Takekawa et al., 2003; Carter et al., 2005; Paulsen et al., 2005). Nonetheless, artificial light allows the experiments to be repeatable under the same irradiation conditions. Smog chambers are, however, not without any limitations or uncertainties in chamber wall effects when evaluating the mechanisms or models (Carter et al., 1982; Carter and Lurmann, 1991; Dodge, 2000). For example, off-gassing of $\mathrm{NO}_{\mathrm{x}}$ and other species from chamber walls may introduce contaminations into the background gas and affect the utility of the data. Similarly, chamber wall effects may lead to large uncertainties when evaluating experiments at low concentrations. Large volume reactors with small surface-to-volume ratios can minimize the wall effects and the wall loss of particles and gas-phase species. Moreover, larger volume allows experiments of longer durations to be conducted and more instruments to be used. Considering these concerns, Tobias and Ziemann (1999) used a $7000 \mathrm{~L}$ Teflon environmental chamber to generate organic aerosols through gas-phase reactions of 1-tetradecene and ozone. Cocker et al. (2001a) developed dual $28 \mathrm{~m}^{3}$ indoor chambers to study the mechanisms of aerosol formation. Recently, to minimize reactor effects in the studies of volatile organic compounds (VOCs) reactivity and SOA formation, Carter et al. (2005) constructed a stateof-the-art indoor chamber facility with two collapsible $90 \mathrm{~m}^{3}$ FEP Teflon film reactors.

In China, some small-volume smog chambers have been developed to study gas-phase kinetic mechanisms since 1980s (Wang et al., 1995; Ren et al., 2005; Xu et al., 2006). Wu et al. (2007) constructed a $2 \mathrm{~m}^{3}$, precisely temperaturecontrolled indoor smog chamber made of FEP Teflon film to study the SOA formation. However, the small volumes of these smog chambers impart the disadvantage of relatively large wall effects and also make it difficult to do experiments of long durations. At present, ozone and fine particles $\left(\mathrm{PM}_{2.5}\right)$ have become serious air quality problems in China (Chan and Yao, 2008; Q. Zhang et al., 2012). As ozone and a large portion of $\mathrm{PM}_{2.5}$ components are secondary from gaseous precursors under atmospheric gas-phase and/or multi-phase processes, it is imperatively necessary to set up further quality smog chambers in China for the deep understanding of complex air pollution, particularly in China's megacities.

This paper describes a new state-of-the-art indoor smog chamber facility established at the Guangzhou Institute of Geochemistry, Chinese Academy Sciences (GIG-CAS). This GIG-CAS chamber facility is designed to study formation mechanisms of ozone and SOA as well as the evolution of SOA; to evaluate the mechanisms, particularly under low$\mathrm{NO}_{\mathrm{x}}$ and VOC conditions; and to serve as a platform for evaluating the performance of newly developed gas or particle monitors. A series of initial characterization experiments have been carried out and are discussed in this paper.

\section{Facility}

The $8.5 \mathrm{~m} \times 4.0 \mathrm{~m} \times 3.5 \mathrm{~m}$ thermally insulated enclosure is housed in a $14.0 \mathrm{~m} \times 6.0 \mathrm{~m} \times 8.5 \mathrm{~m}$ laboratory in the first floor and has been equipped with an array of continuous gas-phase and aerosol-phase monitors. Situated directly over the enclosure on the second floor are offline VOCs/semiVOCs/ions/anions samplers and analyzers. The list of equipment is shown in Table 1 . Inside the enclosure are a $30 \mathrm{~m}^{3}$ reactor made of FEP Teflon film (FEP 100, Type 200A; DuPont, USA) with dimensions of $5.0 \mathrm{~m} \times 3.0 \mathrm{~m} \times 2.0 \mathrm{~m}$ and two banks of $60 \mathrm{~W} 1.22 \mathrm{~m}$ black lamps. A schematic of the GIG-CAS smog chamber is shown in Fig. 1a.

\subsection{Enclosure}

The inner walls of the enclosure are covered with reflective and polished stainless steel sheets to obtain a maximum and homogenous light intensity. The floor is covered with less reflective but more durable stainless steel sheets. For indoor Teflon chambers, air conditioning systems are widely used to control the temperature within the tropospheric temperature range, which is roughly from -60 to $40^{\circ} \mathrm{C}$ (Takekawa et al., 2003; Carter et al., 2005; Paulsen et al., 2005; Wu et al., 2007). The enclosure temperature of our chamber is controlled by three cooling units (total power $40 \mathrm{~kW}$ ), which are located outside the laboratory next to the enclosure. The cooling air is distributed uniformly and constantly in three different ducts through the enclosure false ceiling made of perforated reflective aluminum sheets, and is returned to the cooling units through a porous, highly efficient $3.0 \mathrm{~m} \times 0.2 \mathrm{~m} \times 0.6 \mathrm{~m}$ filter that contains activated charcoal inside to clean the enclosure air. A heater is also installed inside each duct. Eight thermocouples (Fig. 1a) are placed approximately $1 \mathrm{~m}$ above the housing floor between the enclosure and the reactor walls. The enclosure temperature is controlled by an electronic control system through adjusting the power of cooling units and heaters according to the 
Table 1. Overview of instruments.

\begin{tabular}{|c|c|c|c|c|}
\hline Instrument & Measured parameters & DL/Range & Accuracy & Flow rate $(\mathrm{L} \mathrm{min}-1)$ \\
\hline \multirow[t]{2}{*}{ Siemens QFM2160 } & temperature & $0-50{ }^{\circ} \mathrm{C}$ or $-35-35^{\circ} \mathrm{C}$ & $\pm 0.8^{\circ} \mathrm{C}$ & $\mathrm{NA}^{\mathrm{a}}$ \\
\hline & relative humidity & $0-100 \%$ & $\pm 3 \%$ & NA \\
\hline Siemens QBM66.201 & differential pressure & $0-100 \mathrm{~Pa}$ & $\pm 3 \mathrm{~Pa}$ & NA \\
\hline EPP2000CXR-50 concave grating spectrometer & light spectrum & $280-900 \mathrm{~nm}$ & NA & NA \\
\hline Thermo Scientific Model 48i & $\mathrm{CO}$ & $0.04 \mathrm{ppm}$ & $\pm 0.1 \mathrm{ppm}$ & 0.5 \\
\hline Thermo Scientific Model 43i & $\mathrm{SO}_{2}$ & $0.05 \mathrm{ppb}$ & $0.2 \mathrm{ppb}$ or $\pm 1 \% \mathrm{~b}$ & 0.5 \\
\hline Ecotech 9810 & $\mathrm{O}_{3}$ & $0.5 \mathrm{ppb}$ & $0.5 \mathrm{ppb}$ or $\pm 0.5 \% \mathrm{~b}$ & 0.5 \\
\hline Ecotech $9841 \mathrm{~T}$ & $\mathrm{NO} / \mathrm{NO}_{2} / \mathrm{NO}_{\mathrm{x}}$ & $50 \mathrm{ppt}$ & $100 \mathrm{ppt}$ or $\pm 0.5 \% \mathrm{~b}$ & 0.64 \\
\hline Ecotech 9842 & $\mathrm{NO}_{\mathrm{x}} / \mathrm{NH}_{3}$ & $0.5 \mathrm{ppb}$ & $\pm 0.5 \%$ & 0.355 \\
\hline GC-MSD/FID/ECD & VOCs & $<10 \mathrm{ppt}$ & $\pm 5 \%$ & NA \\
\hline PTR-TOF-MS & VOCs & $0.1-5000 \mathrm{ppb}$ & $\pm(5-30) \%$ & 0.5 \\
\hline DNPH-LC-MS & carbonyls & $0.05-0.15 \mu \mathrm{g} \mathrm{m}^{-3}$ & $\pm 3 \%$ & NA \\
\hline \multirow[t]{2}{*}{ SMPS (TSI 3081DMA and 3775 CPC) } & particle number & $1-10^{7} \mathrm{~cm}^{-3}$ & $\pm 10 \%^{\mathrm{c}}$ & 0.3 \\
\hline & particle size & $10-1000 \mathrm{~nm}$ & $\pm(3-3.5) \%$ & \\
\hline HR-TOF-AMS & particle composition & $22 \mathrm{ng} \mathrm{m}^{-3, \mathrm{~d}}$ & NA & 0.1 \\
\hline Metrohm, 883 Basic IC plus & anions and cations & $0.01-0.05 \mu \mathrm{g} \mathrm{m}^{-3}$ & $\pm 3 \%$ & NA \\
\hline
\end{tabular}

${ }^{\mathrm{a}} \mathrm{NA}=$ not applicable. ${ }^{\mathrm{b}}$ Whichever is greater. ${ }^{\mathrm{c}}$ For total number concentration. ${ }^{\mathrm{d}}$ For organics.

difference between the average temperature of the eight thermocouples and the set temperature.

\subsection{Teflon reactor}

Chamber reactor walls can be made of Teflon film (Cocker et al., 2001a; Carter et al., 2005), Pyrex (Doussin et al., 1997), quartz (Barnes et al., 1987), aluminum (Akimoto et al., 1979) or stainless steel (Wang et al., 2011). Except for the AIDA chamber (Saathoff et al., 2003), most larger smog chambers on the order of tens of cubic meters were made of Teflon film for technical and economical reasons (Cocker et al., 2001a; Carter et al., 2005; Pandis et al., 1991; Johnson et al., 2004; Martín-Reviejo and Wirtz, 2005; Rollins et al., 2009). The reactor wall material of this chamber is 2 mil $(54 \mu \mathrm{m})$ FEP Teflon film that is transparent, chemically inert and UV permeable. The Teflon film is flexible enough to avoid altering the pressure inside the reactor during air extraction. The Teflon reactor is self-made by a heat sealing laminator. All seams on the reactor are reinforced by a polyester film tape with a silicone adhesive (polyester tape 8403 ; 3M, USA). The reactor wall is more than $1 \mathrm{~m}$ away from the lights to avoid the heating on the surface of the Teflon film. The reactor is mounted inside the enclosure with a fixed bottom stainless steel frame and a movable top stainless steel frame. The top frame is lifted and lowered by a mechanical step motor that has power-off protection. During experiments, as the volume decreases due to sampling, leaks and permeation, the top frame is lowered slowly to maintain a differential positive pressure between the inside of the reactor and the enclosure, thereby reducing the contamination of the enclosure air. Siemens QBM 66.201 (Siemens AG, Germany) is used to measure the differential pressure between the reactor and the enclosure with an accuracy of $\pm 3 \mathrm{~Pa}$. When the reactor volume decreases to $1 / 3$ of its maximum value, the experiment (typically about $10 \mathrm{~h}$, depending on the numbers of instruments taking samples from the chamber) is terminated. When lowering the top frame of the reactor during wall loss evaluation experiments, the total particle number concentration $\left(N_{\mathrm{t}}\right)$ changed smoothly from an initial number concentration $N_{0}$ and the slope of $\ln \left(N_{0} / N_{\mathrm{t}}\right)$ versus $t$ remained constant, suggesting that the movement of the chamber will not affect the aerosol wall loss rates.

Four Teflon ports are installed inside the reactor. One port located in the middle of the chamber floor has 12 holes of $0.635 \mathrm{~cm}$ in diameter. This port is used for injection of purified air, sample and seed aerosols. A second port next to the instruments, with 13 holes of $0.635 \mathrm{~cm}$ in diameter, is used for sampling. Since the residence time of air inside the sampling lines is within seconds, the influence of sampling process on the homogeneity of air reaching the online instruments is negligible. The other two ports, each with four holes of $0.635 \mathrm{~cm}$ in diameter, are also used for sampling. Furthermore, an air blower is connected to the reactor through a $10 \mathrm{~cm}$ solenoid valve controlled by computer, providing a pumping flow rate of $1 \mathrm{~m}^{3} \mathrm{~min}^{-1}$ to evacuate the reactor.

Two three-wing stainless steel fans coated with Teflon are installed at the bottom inside the reactor to provide sufficient mixing of the gas species and particles. No detectable nonmethane hydrocarbons (NMHCs) are emitted from the fans. Rotating speed of the fans can be varied to a maximum of $1400 \mathrm{rpm}$ by adjusting the input power.

\subsection{Light source}

A total of 135 black lamps $(1.2 \mathrm{~m}$ long, $60 \mathrm{~W}$ Philips/10R BL; Royal Dutch Philips Electronics Ltd, the Netherlands) are arranged in two banks as the light 

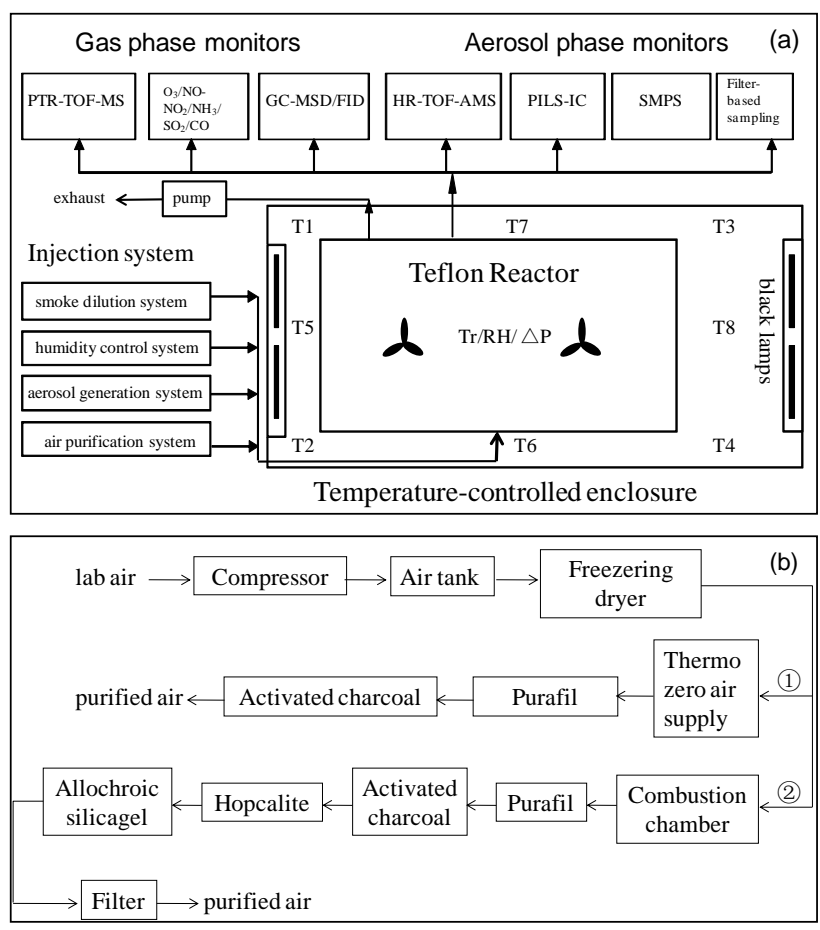

Fig. 1. (a) Schematic of the GIG-CAS smog chamber facility. T1$\mathrm{T} 8$ are the thermocouples in the enclosure and $T_{\mathrm{r}}$ is the temperature sensor inside the reactor. (b) Schematic of two air purification systems. Route 1 represents the procedures of the Thermo zero-air supply system; route 2 represents the procedures of the larger flow rate air purification system.

source. One bank of 80 lamps is mounted on one enclosure wall, and another bank of 55 lamps is mounted near the opposite enclosure wall on an aluminum alloy frame. The artificial light produced by the black lamps gives a good representation of the ground-level solar light spectrum in the low-wavelength region, but they do not emit in the longer wavelength regions (> $400 \mathrm{~nm}$ ) that photolyze some species, such as peroxy radicals or methylglyoxal in the range of 450-550 nm (Cocker et al., 2001a). However, because of the low-cost and efficient UV irradiation, black lamps are frequently used in environment chamber experiments (Cocker et al., 2001a; Carter et al., 2005; Hynes et al., 2005; $\mathrm{Wu}$ et al., 2007). The 135 black lamps are divided into 4 separately controlled groups; therefore the light intensity can be regulated to different levels. During the experiments, a $J_{\mathrm{NO}_{2}}$ filter radiometer (Metcon $\mathrm{GmbH}$, Germany) is used to monitor the light intensity inside the enclosure.

\subsection{Air purification system}

As matrix gas for simulation experiments and carrier gas for reactants, purified dry air is supplied by passing compressed house air through a condenser and a Thermo zero-air supply (Model 1160; Thermo Scientific, USA). The maximum flow rate of purified air is $45 \mathrm{~L} \mathrm{~min}^{-1}$. The purified dry air includes $<0.5 \mathrm{ppb} \mathrm{NMHCs},<1 \mathrm{ppb} \mathrm{NO}_{\mathrm{x}}, \mathrm{O}_{3}$ and carbonyl compounds, and no detectable particles. A separate source of purified air with $<5$ ppb NMHCs (mainly ethane and propane) is also used for high-concentration precursor (hundreds of parts per billion) experiments. Compressed indoor air is forced through a combustion chamber filled with Hopcalite and a series of bed scrubbers containing activated charcoal, Purafil, Hopcalite and allochroic silica gel, followed by a PTFE filter to provide this source of purified air with a maximum flow rate of $200 \mathrm{~L} \mathrm{~min}^{-1}$. The schematic of these two air purification systems is shown in Fig. 1b.

Before each experiment the reactor is evacuated and filled with purified dry air at least five times, then the reactor is flushed with purified dry air at a flow rate of $100 \mathrm{~L} \mathrm{~min}^{-1}$ for at least $48 \mathrm{~h}$ until no residual hydrocarbons, $\mathrm{O}_{3}, \mathrm{NO}_{\mathrm{x}}$ or particles are detected in the reactor to avoid carry-over problems from day-to-day experiments. When the reactor is not in use, it is continuously flushed with purified dry air.

\subsection{Injection system}

Gaseous reactants are injected using gas-tight syringes through a septum installed in one port of a union tee that is connected to a FEP Teflon line, and then flushed by purified dry air or nitrogen into the reactor. For the introduction of liquid reactants, known volumes are measured and injected by means of microliter syringes through a heating system with an injection port similar to that used in gas chromatography. The temperature of the injection port is adjustable according to boiling points of the injected reactants. Ozone is generated by a commercial ozone generator (VMUS-4; Azco Industries Ltd, Canada) with pure oxygen as the feed gas to prevent the generation of $\mathrm{NO}_{\mathrm{x}}$. Ozone introduced into the reactor is controlled by the generating time and the flow rate.

Humidification is achieved by vaporizing Milli-Q ultrapure water contained in a $0.5 \mathrm{~L}$ Florence flask and the water vapor is flushed with purified dry air into the reactor. Relative humidity inside the reactor can be varied from $<5$ to $80 \%$. The humidification process does not introduce detectable hydrocarbons or particles into the reactor.

Seed particles are generated by an atomizer (ATM-220; Topas GmbH, Germany) and pass through a diffusion dryer (DDU-570; Topas GmbH, Germany) to remove water and a neutralizer (TSI 3080; TSI Incorporated, USA) to eliminate the charge before introducing into the reactor.

\subsection{Instrumentation}

The array of gas-phase and aerosol-phase instruments equipped with the chamber facility is briefly described in Table 1.

Ozone is measured by an EC9810 ozone analyzer (Ecotech, Australia), which is calibrated weekly using a 
Thermo Scientific Model 146i multi-gas calibrator. The detection limit and accuracy of the ozone instrument are $0.5 \mathrm{ppb}$ and $\pm 0.5 \%$, respectively. An EC9841T chemiluminescence analyzer (Ecotech, Australia) is used to measure $\mathrm{NO}$ and $\mathrm{NO}_{2}$. The $\mathrm{NO}_{\mathrm{x}}$ instrument is calibrated weekly using a certified cylinder of NO. The detection limit and accuracy of the $\mathrm{NO}_{\mathrm{x}}$ instrument are $50 \mathrm{ppt}$ and $\pm 0.5 \%$, respectively.

VOCs inside the reactor are measured both offline and online. Offline measurement are performed by using a model 7100 preconcentrator (Entech Instruments Inc., USA) coupled with an Agilent 5973N gas chromatography-mass selective detector/flame ionization detector/electron capture detector (GC-MSD/FID/ECD; Agilent Technologies, USA). During simulation, air inside the reactor is sampled about every $15 \mathrm{~min}$ with evacuated $2 \mathrm{~L}$ stainless steel canisters and simultaneously analyzed with the three detectors of this selfmodified system for a wide spectrum of VOCs. This analytical system is well established, and a detailed description of the method can be found elsewhere (Wang and $\mathrm{Wu}, 2008$; Y. L. Zhang et al., 2010, 2012, 2013). Carbonyl compounds are analyzed offline by high-performance liquid chromatography (HPLC - HP1200; Agilent Technologies, USA) coupled to UV detection at $360 \mathrm{~nm}$ after being collected by drawing air through a Sep-Pak DNPH-Silica cartridge (Waters Corporation, USA) with a sampling pump (Thomas, USA) every $15 \mathrm{~min}$. A detailed description of the method can be found elsewhere (Tang et al., 2003).

Online monitoring of parent NMHCs such as propene, $\alpha$ pinene, and some aromatic hydrocarbons as well as their oxidation products are also available with a proton-transferreaction time-of-flight mass spectrometer (PTR-TOF-MS; Ionicon Analytik $\mathrm{GmbH}$, Austria). Detailed descriptions of the PTR-TOF-MS technique can be found elsewhere (Lindinger et al., 1998; Jordan et al., 2009). At present the accuracies for some species by the PTR-TOF-MS are still not comparable to that by offline methods: for example, PTR-MS quantification of $\mathrm{HCHO}$ is highly influenced by the humidity (Vlasenko et al., 2010). Therefore in this work we only report our VOCs results by offline techniques, and further calibration of the PTR-TOF-MS is still under way.

Particle number concentrations and size distributions are obtained using a scanning mobility particle sizer equipped with a differential mobility analyzer (TSI 3081; TSI Incorporated, USA) and a condensation particle counter (TSI 3775; TSI Incorporated, USA). Flow rates of sheath and aerosol flow are 3.0 and $0.3 \mathrm{~L} \mathrm{~min}^{-1}$, respectively, allowing for a size distribution scan ranging from 14 to $700 \mathrm{~nm}$ within $135 \mathrm{~s}$. The accuracy of the particle number concentration is $\pm 10 \%$.

A high-resolution time-of-flight aerosol mass spectrometer (HR-TOF-MS; Aerodyne Research Incorporated, USA) is used to measure the chemical compositions and evolutions of submicron aerosols $\left(\mathrm{PM}_{1}\right)$ (Jayne et al., 2000; DeCarlo et al., 2006). The HR-TOF-MS is also able to determine the average element ratios of organics, like $\mathrm{H} / \mathrm{C}, \mathrm{O} / \mathrm{C}$, and $\mathrm{N} / \mathrm{C}$ (Aiken et al., 2007, 2008). The instrument is operated
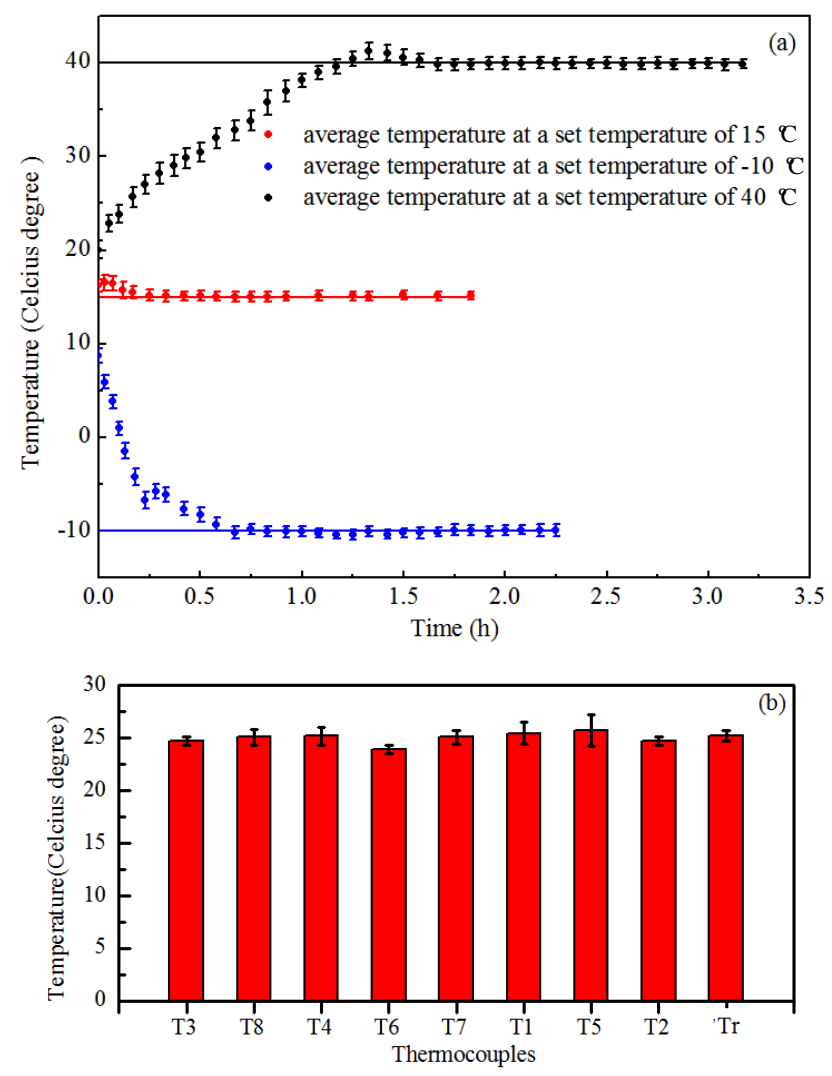

Fig. 2. (a) Evolutions of the average temperature of nine thermocouples, eight of them outside the reactor and one inside the reactor (see Fig. 1a), under black light irradiation condition. Error bars are the standard deviations of the nine temperatures. The solid lines represent set temperatures. (b) Average temperature values measured by the nine thermocouples over a $6 \mathrm{~h}$ period under black light irradiation condition. Error bars show the temperature variability in the $6 \mathrm{~h}$ period.

in the high-sensitivity $\mathrm{V}$ mode and high-resolution $\mathrm{W}$ mode alternatively. The HR-TOF-MS is calibrated using $300 \mathrm{~nm}$ monodisperse ammonium nitrate particles.

\section{Characterization}

\subsection{Temperature control and its homogeneity}

In the GIG-CAS chamber, three temperature control units and two Teflon-coated fans are used to provide a homogeneous and stable temperature inside the reactor. Figure 2a shows evolutions of the average temperatures as measured by the eight thermocouples (T1-T8, Fig. 1a) and the temperature inside the reactor $\left(T_{\mathrm{r}}\right.$, Fig. 1b) measured by Siemens QFM2160 (Siemens AG, Germany) under black light irradiation when temperatures were set to 40,15 and $-10^{\circ} \mathrm{C}$, respectively. After the initial increase or decrease, the average temperatures stabilized after about $1.5 \mathrm{~h}, 20 \mathrm{~min}$ and $40 \mathrm{~min}$ 


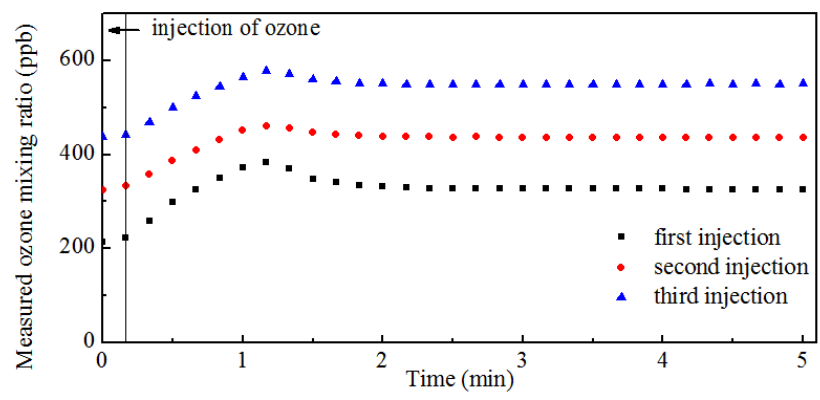

Fig. 3. Concentration-time plot of ozone after each injection. The two mixing fans rotated at a speed of $700 \mathrm{rpm}$ in the experiments.

when the temperatures were set to 40,15 and $-10^{\circ} \mathrm{C}$, respectively. The standard deviations of the nine temperatures were all within $\pm 1{ }^{\circ} \mathrm{C}$, indicating a good homogeneity of the temperature inside the enclosure and the reactor.

The average values of $\mathrm{T} 1$ to $\mathrm{T} 8$ and $T_{\mathrm{r}}$ at a set temperature of $25^{\circ} \mathrm{C}$ with all the black lamps switched on are shown in Fig. 2b. The experiment duration time was $6 \mathrm{~h}$. All of the eight thermocouples show stable temperatures around $25^{\circ} \mathrm{C}$ with accuracies within $\pm 1^{\circ} \mathrm{C}$. Temperature inside the reactor is stable at $25.2 \pm 0.5^{\circ} \mathrm{C}$ during the experiment. All the subsequent experiments were carried out at a set temperature of $25^{\circ} \mathrm{C}$ with a relative humidity less than $10 \%$.

\subsection{Mixing}

Ozone is chosen as a tracer to test the gas-phase mixing time inside the reactor. The injection line was in the middle of the reactor near a fan. Ozone was generated at a rate of $0.8 \mathrm{~L} \mathrm{~min}^{-1}$ for $10 \mathrm{~s}$ and was injected into the reactor in three pulses. While higher rotation speed of fans provides better mixing inside the enclosure, wall loss rates were found to increase with rotation speed of the fan (Saathoff et al., 2003; Bloss et al., 2005; Carter et al., 2005; Wang et al., 2011). To make a balance between lower wall loss and better mixing, we finally settled on a fan rotation speed of $700 \mathrm{rpm}$. At this speed, ozone can be well mixed in about $120 \mathrm{~s}$ after each injection (Fig. 3). Compared to the experiment's duration, which may be several hours, this mixing time is very short. Tests with other compounds, like $\alpha$-pinene, also revealed fairly good mixing within $1 \mathrm{~min}$.

\subsection{Dilution}

Dilution may occur due to small leaks or high-volume sampling. Dilution rate may vary with the number and type of instruments taking samples from the reactor. In each experiment, a low-reactive compound such as $\mathrm{SF}_{6}$ or $\mathrm{CH}_{3} \mathrm{CN}$ was injected as a tracer for dilution. Dilution was not detectable within the uncertainty of the instrument.

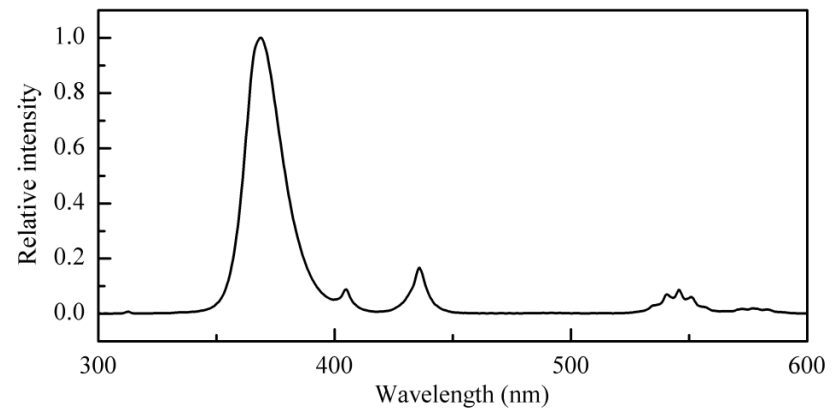

Fig. 4. Measured spectrum of black lamps.

\subsection{Light spectrum and intensity}

The light spectrum emitted by black lamps is measured by EPP2000CXR-50 concave grating spectrometer (StellarNet Inc, USA) and is shown in Fig. 4. The black lamps produce an irradiation over the range from 340 to $400 \mathrm{~nm}$ with peak intensity at $369 \mathrm{~nm}$. For the wavelength above $400 \mathrm{~nm}$, essentially no intensity is produced except for some small peaks. In the first 8 months of operation, no appreciable variation of the light spectrum was observed.

Light intensity is represented by the photolysis rate of $\mathrm{NO}_{2}$, which is estimated by a steady-state actinometry. The operation process includes injecting $\mathrm{NO}_{2}$ into the reactor, irradiating it and continuously measuring the concentrations of $\mathrm{NO}, \mathrm{NO}_{2}$ and $\mathrm{O}_{3}$. The photolysis rate of $\mathrm{NO}_{2}, \mathrm{~J}_{\mathrm{NO}_{2}}$, is estimated according to the equation

$J_{\mathrm{NO}_{2}}=k_{\mathrm{NO}+\mathrm{O}_{3}}[\mathrm{NO}]\left[\mathrm{O}_{3}\right] /\left[\mathrm{NO}_{2}\right]$,

where $[\mathrm{NO}],\left[\mathrm{O}_{3}\right]$ and $\left[\mathrm{NO}_{2}\right]$ represent concentrations (molecule $\mathrm{cm}^{-3}$ ) and $k_{\mathrm{NO}+\mathrm{O}_{3}}$ (Atkinson et al., 2004) is the rate constant of ozone and $\mathrm{NO}$ reaction. A series of $\mathrm{NO}_{2}$ actinometry experiments were carried out. $\mathrm{A} \mathrm{NO}_{2}$ photolysis rate of $0.49 \pm 0.01 \mathrm{~min}^{-1}$ at full light intensity was obtained (corrected for the reaction of ozone and NO in the sampling lines). This value is a little lower than $0.58 \mathrm{~min}^{-1}$ calculated by TUV/NCAR model for Guangzhou on 22 June at noon. The four separately controlled groups of black lamps allow the $\mathrm{NO}_{2}$ photolysis rate to be varied from 0 to $0.49 \mathrm{~min}^{-1}$.

\subsection{Wall loss of gases}

Chamber wall effects include off-gassing of $\mathrm{NO}_{\mathrm{x}}$ and other reactive species, chamber radical sources and gas losses to the walls (Carter et al., 1982). They may have an impact on gas-phase reactivity and secondary organic aerosol formation. In early times of smog chambers, Grosjean (1985) performed a series of experiments to evaluate the wall loss rates of inorganic and organic species.

In the GIG-CAS smog chamber, wall loss rates of NO, $\mathrm{NO}_{2}, \mathrm{O}_{3}$ and propene were evaluated by injecting a certain concentration of these gases and continuous monitoring their decay in the dark. Wall loss rates are obtained by 
Table 2. Summary of wall loss rates of gas species in GIG-CAS chamber and comparison with other chamber facilities.

\begin{tabular}{|c|c|c|c|c|c|c|c|}
\hline \multirow[b]{2}{*}{ Species } & \multirow[b]{2}{*}{$\begin{array}{l}\text { Run } \\
\text { numbers }\end{array}$} & \multirow[b]{2}{*}{$\begin{array}{l}\text { Temp } \\
(\mathrm{K})\end{array}$} & \multirow[b]{2}{*}{$\begin{array}{l}\mathrm{RH} \\
(\%)\end{array}$} & \multicolumn{4}{|c|}{ Wall loss rate $\left(\times 10^{-4} \min ^{-1}\right)$} \\
\hline & & & & $\begin{array}{l}\text { GIG-CAS } \\
\left(30 \mathrm{~m}^{3}\right)\end{array}$ & $\begin{array}{l}\mathrm{ERT}^{\mathrm{a}} \\
\left(60 \mathrm{~m}^{3}\right)\end{array}$ & $\begin{array}{l}\text { EUPHORE }^{b} \\
\left(200 \mathrm{~m}^{3}\right)\end{array}$ & $\begin{array}{l}\mathrm{PSI}^{\mathrm{c}} \\
\left(27 \mathrm{~m}^{3}\right)\end{array}$ \\
\hline $\mathrm{O}_{3}$ & 4 & 296.7 & $<10$ & $1.31 \pm 0.24$ & $0.5-3$ & 1.8 & 2.4 \\
\hline $\mathrm{NO}$ & 9 & 296.7 & $<10$ & $1.41 \pm 0.40$ & $0-5.4$ & $\mathrm{NA}^{\mathrm{d}}$ & NA \\
\hline $\mathrm{NO}_{2}$ & 4 & 296.7 & $<10$ & $1.39 \pm 0.68$ & $0-2$ & NA & $0.13-2.52$ \\
\hline
\end{tabular}

${ }^{a}$ Grosjean (1985). ${ }^{b}$ Bloss et al. (2005). ${ }^{c}$ Metzger et al. (2008). ${ }^{d}$ NA $=$ not applicable.

treating the wall loss as a first-order process. The average wall loss rates of $\mathrm{NO}, \mathrm{NO}_{2}$ and $\mathrm{O}_{3}$ were $1.41 \times 10^{-4} \mathrm{~min}^{-1}$, $1.39 \times 10^{-4} \mathrm{~min}^{-1}$ and $1.31 \times 10^{-4} \mathrm{~min}^{-1}$, respectively. They are all within the range of reported values of other chamber facilities (Table 2). For propene, Wu et al. (2007) calculated a wall loss rate of $1.1 \times 10^{-7} \mathrm{~s}^{-1}$ in a $2 \mathrm{~m}^{3}$ Teflon smog chamber. While in our GIG-CAS smog chamber, no wall loss of propene was observed within the uncertainty of GC-FID. Unlike $\mathrm{NO}, \mathrm{NO}_{2}$ and $\mathrm{O}_{3}$ that might be lost to the reactor walls due to heterogeneous reactions, wall loss rate of propene was relatively small and not detectable.

\subsection{Particle wall loss}

Particle deposition onto the wall of the reactor is believed to be influenced by diffusion and the charged wall. Particle wall loss rate is proportional to the particle concentration and depends on the particle size. The particle number-weighted wall loss rate is described by first-order kinetics as

$\frac{\mathrm{d} N\left(d_{\mathrm{p}}, t\right)}{\mathrm{d} t}=-K_{N}\left(d_{\mathrm{p}}\right) N\left(d_{\mathrm{p}}, t\right)$

where $N\left(d_{\mathrm{p}}, t\right)$ is the particle number concentration, $d_{\mathrm{p}}$ is the diameter of the particle and $K_{N}\left(d_{\mathrm{p}}\right)$ is the particle number loss coefficient (Cocker et al., 2001a). The $K_{N}\left(d_{\mathrm{p}}\right)$ values can be estimated from the particle number concentration versus time data in any experiment when no new particle is formed.

Ammonium sulfate $\left(\left(\mathrm{NH}_{4}\right)_{2} \mathrm{SO}_{4}, \mathrm{AS}\right)$ seed particles are introduced into the reactor to evaluate the production of water-soluble inorganic particles and the particle number wall loss. AS solution amounting to $0.5 \mathrm{~mol} \mathrm{~L}^{-1}$ was atomized with a flow rate of $0.5 \mathrm{~L} \mathrm{~min}^{-1}$ for $20 \mathrm{~min}$. As shown in Fig. 5, AS aerosols exhibit a median diameter of $150 \mathrm{~nm}$ within a few minutes after the injection and the median diameter slowly increases to $200 \mathrm{~nm}$ due to coagulation of smaller particles and probably higher wall loss rate of smaller particles. For aerosols with $d_{\mathrm{p}}$ of 60,100, 200, 300 and $400 \mathrm{~nm}$, $K_{N}$ was determined to be $0.41,0.23,0.12,0.08$ and $0.10 \mathrm{~h}^{-1}$, respectively. Like the study by Takekawa et al. (2003), our results also suggest that smaller particles deposit more easily onto the reactor walls. For aerosols with $d_{\mathrm{p}}=300 \mathrm{~nm}$, the wall loss rate of $0.08 \mathrm{~h}^{-1}$ is close to but lower than that of

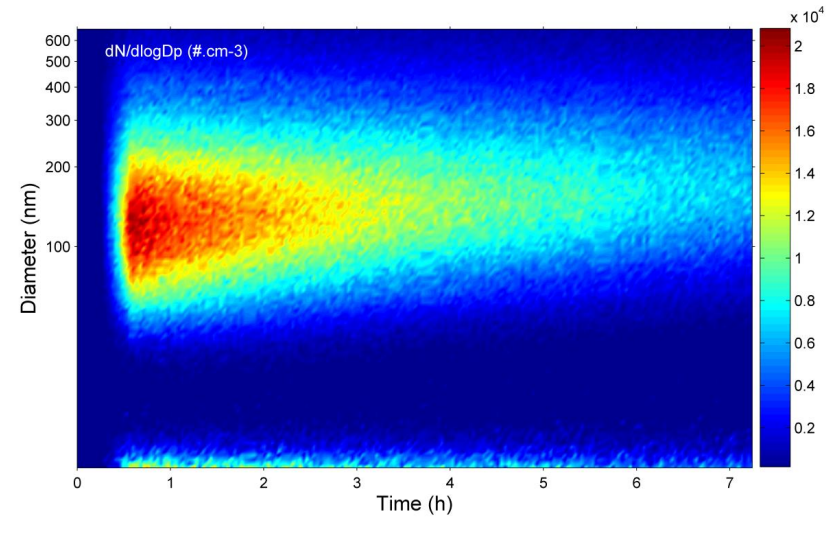

Fig. 5. Number concentration distribution of $\left(\mathrm{NH}_{4}\right)_{2} \mathrm{SO}_{4}$ as a function of time after its introduction into the reactor.

$0.10 \mathrm{~h}^{-1}$ reported for the TCRDL chamber (Takekawa et al., 2003). The particle number wall loss rate is determined to be $0.17 \mathrm{~h}^{-1}$, which means a lifetime of $5.9 \mathrm{~h}$ for particles. The result is comparable to results reported for other smog chambers (Table 3).

\subsection{Propene- $\mathrm{NO}_{\mathrm{x}}$ experiments}

The propene- $\mathrm{NO}_{\mathrm{x}}$ irradiation system was widely used as a reference system (Carter et al., 2005; Hynes et al., 2005) to evaluate the ability of a chamber to test the mechanisms for single organic $-\mathrm{NO}_{\mathrm{x}}$ irradiation systems. A set of four propene- $\mathrm{NO}_{\mathrm{x}}$ irradiation runs were carried out under dry conditions with a controlled temperature of $298.3 \pm 0.5 \mathrm{~K}$. The initial experimental conditions are listed in Table 4 . The initial propene concentrations varied from 669 to $967 \mathrm{ppb}$ and the initial propene $/ \mathrm{NO}_{\mathrm{x}}$ ratios ranged from 1.8 to 2.6.

A near-explicit mechanism for propene from the Master Chemical Mechanism version 3.2 (Saunders et al., 2003) was used to simulate the propene- $\mathrm{NO}_{\mathrm{x}}$ irradiation experiments. Auxiliary mechanisms and relevant parameters used in the model are listed in Table 5. The parameters were determined by simulating clean air, low $\mathrm{NO}_{\mathrm{x}}$-air, $\mathrm{CO}-\mathrm{NO}_{\mathrm{x}}$-air and $\mathrm{CO}-$ air irradiation experiments. Reaction rate coefficients of the $\mathrm{N}_{2} \mathrm{O}_{5}$ hydrolysis to adsorbed $\mathrm{HNO}_{3}$, the photolysis of adsorbed $\mathrm{HNO}_{3}$ to $\mathrm{OH}$ and $\mathrm{NO}_{2}$, and the wall loss of $\mathrm{HNO}_{3}$ 
Table 3. Comparison of particle wall loss rates in different smog chambers.

\begin{tabular}{lrlrrl}
\hline Chamber & $\begin{array}{r}\text { Volume } \\
\left(\mathrm{m}^{3}\right)\end{array}$ & $\begin{array}{l}\text { Wall } \\
\text { material }\end{array}$ & $\begin{array}{r}\text { Wall loss } \\
\text { rate }\left(\mathrm{h}^{-1}\right)\end{array}$ & $\begin{array}{r}\text { Particle } \\
\text { lifetime }(\mathrm{h})\end{array}$ & Reference \\
\hline GIG-CAS & 30 & FEP & 0.17 & 5.9 & This work \\
PSI & 27 & FEP & 0.21 & 4.8 & Paulsen et al. (2005) \\
Caltech & 28 & FEP & 0.20 & 5.0 & Cocker et al. (2001a) \\
UCR & 90 & FEP & 0.29 & 3.4 & Carter et al. (2005) \\
EUPHORE & 200 & FEP & 0.18 & 5.6 & Martín-Reviejo and Wirtz (2005) \\
SAPHIR & 270 & FEP & 0.27 & 3.7 & Rollins et al. (2009) \\
CMU & 12 & FEP & 0.40 & 2.5 & Donahue et al. (2012) \\
\hline
\end{tabular}

Table 4. Summary of initial conditions for propene- $\mathrm{NO}_{\mathrm{x}}$-air irradiation experiments.

\begin{tabular}{llrrrrrr}
\hline $\begin{array}{l}\text { Run } \\
\text { number }\end{array}$ & $T(\mathrm{~K})$ & $\begin{array}{r}\mathrm{RH} \\
\%\end{array}$ & $\begin{array}{r}\mathrm{J}_{\mathrm{NO}_{2}} \\
\mathrm{~min}^{-1}\end{array}$ & $\begin{array}{r}{[\text { propene }]_{0}} \\
\mathrm{ppb}\end{array}$ & $\begin{array}{r}{[\mathrm{NO}]_{0}} \\
\mathrm{ppb}\end{array}$ & $\begin{array}{r}{\left[\mathrm{NO}_{2}\right]_{0}} \\
\mathrm{ppb}\end{array}$ & {$[$ propene]/[NO $]$} \\
\hline 1 & $298.2 \pm 0.5$ & $<10$ & 0.49 & 878 & 215 & 126 & 2.6 \\
2 & $298.2 \pm 0.3$ & $<10$ & 0.49 & 967 & 132 & 292 & 2.3 \\
3 & $297.9 \pm 0.3$ & $<10$ & 0.34 & 930 & 447 & 2.6 & 2.1 \\
4 & $299.0 \pm 0.8$ & $<10$ & 0.49 & 669 & 350 & 19 & 1.8 \\
\hline
\end{tabular}

were assumed similar to those used by Hynes et al. (2005). The reaction rate coefficient of the $\mathrm{NO}_{2}$ dark, heterogeneous reaction $\mathrm{NO}_{2} \rightarrow 0.5 \mathrm{HONO}+0.5 w \mathrm{HNO}_{3}$ was determined to be $2.32 \times 10^{-6} \mathrm{~s}^{-1}$ from $\mathrm{NO}_{2}$ dark decay experiments. As mentioned above, the ozone and NO wall loss rates were determined to be $2.19 \times 10^{-6} \mathrm{~s}^{-1}\left(1.31 \times 10^{-4} \mathrm{~min}^{-1}\right)$ and $2.34 \times 10^{-6} \mathrm{~s}^{-1}\left(1.41 \times 10^{-4} \mathrm{~min}^{-1}\right)$, respectively. The reaction rate coefficients of light-induced production of $\mathrm{OH}$ and off-gassing of $\mathrm{NO}_{2}$ from Teflon walls (Carter and Lurmann, 1991; Bloss et al., 2005) were determined to be $0.005 \mathrm{~J}_{\mathrm{NO}_{2}}$ by simulating the experiments. The initial HONO concentration was varied from 0 to $5 \mathrm{ppb}$ in order to give best fits to the experimental concentration profiles.

Figure 6 shows a comparison of observed and simulated concentration-time profiles of a propene- $\mathrm{NO}_{\mathrm{x}}$ irradiation system. The initial HONO concentration was adjusted to be $5 \mathrm{ppb}$ in order to give the best fit for this experiment. Good agreements are obtained for most of the compounds such as propene, $\mathrm{O}_{3}$, NO, $\mathrm{HCHO}$ and $\mathrm{CH}_{3} \mathrm{CHO}$. The peak $\mathrm{NO}_{2}$ concentration is overpredicted; this phenomenon was also observed by Hynes et al. (2005) for the propene- $\mathrm{NO}_{\mathrm{x}}$ photolysis experiments or by Bloss et al. (2005) and Zádor et al. (2005) for ethene- $\mathrm{NO}_{\mathrm{x}}$ photolysis experiments. For better simulation, some unknown mechanisms involving $\mathrm{NO}_{2}$ sinks most likely need to be included. The model shows a faster sink for $\mathrm{NO}_{2}$ in the last $1 \mathrm{~h} . \mathrm{O}_{3}$ is overpredicted at the end of the experiment with a relative deviation of $4.8 \%$. The quantity $\Delta\left(\left[\mathrm{O}_{3}\right]-[\mathrm{NO}]\right)$ is used to evaluate the model performance (Carter et al., 2005; Pinho et al., 2006). This quantity is defined as
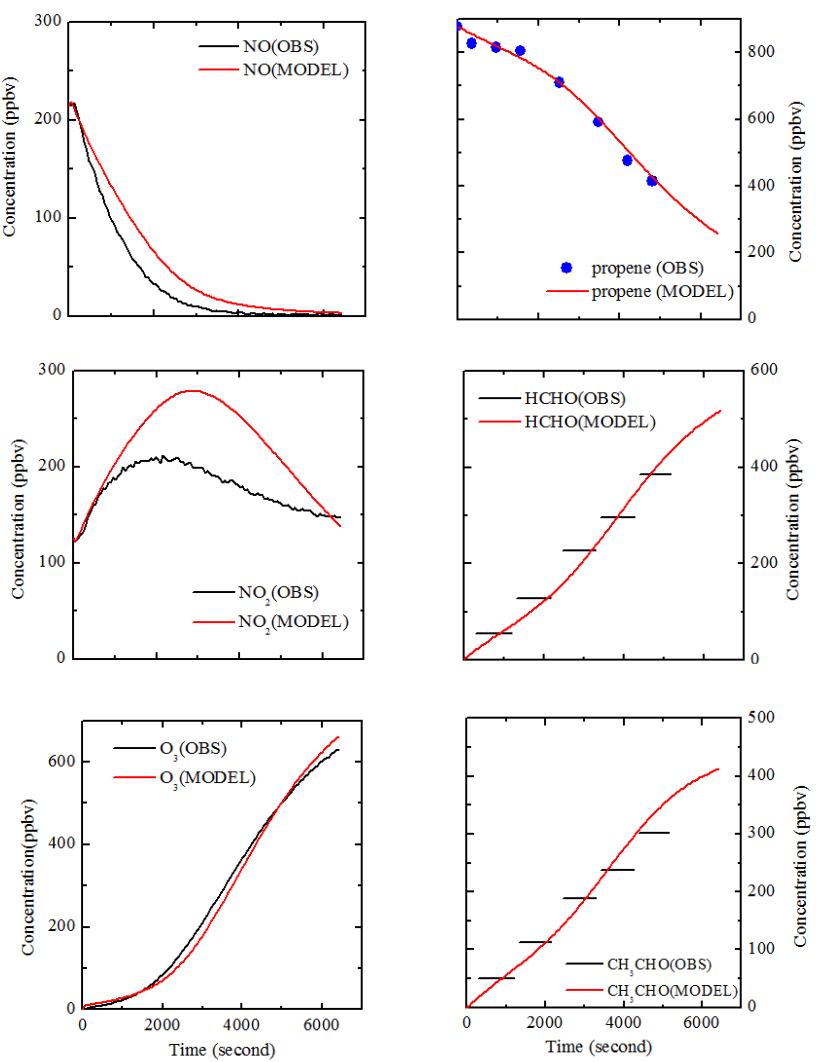

Fig. 6. Concentration-time plots of observed and simulated NO, $\mathrm{NO}_{2}, \mathrm{O}_{3}$, propene, $\mathrm{HCHO}$ and $\mathrm{CH}_{3} \mathrm{CHO}$ in a propene- $\mathrm{NO}_{\mathrm{x}}$-air irradiation system. 
Table 5. Auxiliary mechanisms for chamber-dependent reactions.

\begin{tabular}{lll}
\hline Reaction & Parameters & Lower/Upper limits \\
\hline$h v \stackrel{\text { wall }}{\longrightarrow} \mathrm{NO}_{2}$ & $0.005 J_{\mathrm{NO}_{2}} \mathrm{ppbv} \mathrm{s}^{-1}$ & $(0.0025-0.010) J_{\mathrm{NO}_{2}} \mathrm{ppbv} \mathrm{s}^{-1}$ \\
$h v \stackrel{\text { wall }}{\longrightarrow} \mathrm{OH}$ & $0.005 J_{\mathrm{NO}_{2}} \mathrm{ppbv} \mathrm{s}^{-1}$ & $(0.0025-0.010) J_{\mathrm{NO}_{2}} \mathrm{ppbv} \mathrm{s}^{-1}$ \\
$\mathrm{NO}_{2} \rightarrow 0.5 \mathrm{HONO}+w \mathrm{HNO}_{3}^{*}$ & $2.31 \times 10^{-6} \mathrm{~s}^{-1}$ & $(1.17-3.45) \times 10^{-6} \mathrm{~s}^{-1}$ \\
$\mathrm{~N}_{2} \mathrm{O}_{5} \longrightarrow 2 w \mathrm{HNO}$ & $1 \times 10^{-5} \mathrm{~s}^{-1}$ & $(0.5-2.0) \times 10^{-6} \mathrm{~s}^{-1}$ \\
$\mathrm{~N}_{2} \mathrm{O}_{5}+\mathrm{H}_{2} \mathrm{O} \longrightarrow 2 w \mathrm{HNO}_{3}$ & $1 \times 10^{-20} \mathrm{~cm}^{3}$ molecule $^{-1} \mathrm{~s}^{-1}$ & $(0.1-10) \times 10^{-20} \mathrm{~cm}^{3}$ molecule $^{-1} \mathrm{~s}^{-1}$ \\
$w \mathrm{HNO}_{3} \stackrel{h v}{\longrightarrow} \mathrm{OH}+\mathrm{NO}_{2}$ & $J_{\mathrm{HNO}_{3}}$ & $(0.5-2.0) J_{\mathrm{HNO}_{3}}$ \\
$\mathrm{HNO}_{3} \rightarrow w \mathrm{HNO} \mathrm{HN}_{3}$ & $1 \times 10^{-4} \mathrm{~s}^{-1}$ & $(0.5-2.0) \times 10^{-4} \mathrm{~s}^{-1}$ \\
$\mathrm{NO} \longrightarrow w \mathrm{NO}$ & $2.34 \times 10^{-6} \mathrm{~s}^{-1}$ & $(1.68-3.00) \times 10^{-6} \mathrm{~s}^{-1}$ \\
$\mathrm{O}_{3} \longrightarrow w \mathrm{O}_{3}$ & $2.19 \times 10^{-6} \mathrm{~s}^{-1}$ & $(1.79-2.59) \times 10^{-6} \mathrm{~s}^{-1}$ \\
{$[\mathrm{HONO}]_{0}$} & Varied from $0-5 \mathrm{ppb}$ & \\
\hline
\end{tabular}

* $w \mathrm{HNO}_{3}$ represents adsorbed $\mathrm{HNO}_{3}$ on the wall; similarly, $w \mathrm{NO}$ and $w \mathrm{O}_{3}$ represent adsorbed $\mathrm{NO}$ and $\mathrm{O}_{3}$, respectively.

Table 6. Summary of initial conditions and results for $\alpha$-pinene ozonolysis experiments.

\begin{tabular}{llrrrrrr}
\hline $\begin{array}{l}\text { Run } \\
\text { number }\end{array}$ & $T(\mathrm{~K})$ & $\mathrm{RH}(\%)$ & $\begin{array}{r}{[\alpha-\text { pinene }]_{0}} \\
\mathrm{ppb}\end{array}$ & $\begin{array}{r}\left.\mathrm{CO}_{3}\right]_{0} \\
\mathrm{ppb}\end{array}$ & $\begin{array}{r}\Delta \mathrm{ROG}^{-3} \\
\mu \mathrm{g} \mathrm{m}^{-3}\end{array}$ & $Y$ \\
\hline 1 & $296 \pm 0.4$ & $<5$ & 69.7 & 179 & 390.9 & 114.2 & 0.292 \\
2 & $295 \pm 0.6$ & $<5$ & 21.8 & 425 & 122.4 & 23.9 & 0.195 \\
3 & $294 \pm 0.5$ & $<5$ & 87.2 & 435 & 492.4 & 190.8 & 0.387 \\
4 & $292 \pm 1.8$ & $<5$ & 34.7 & 806 & 196.8 & 45.1 & 0.229 \\
5 & $292 \pm 0.7$ & $<5$ & 13.1 & 626 & 74.2 & 4.98 & 0.067 \\
\hline
\end{tabular}

$\Delta\left(\left[\mathrm{O}_{3}\right]-[\mathrm{NO}]\right)=\left[\mathrm{O}_{3}\right]_{\text {final }}-[\mathrm{NO}]_{\text {final }}-\left(\left[\mathrm{O}_{3}\right]_{0}-[\mathrm{NO}]_{0}\right)$

where $[\mathrm{NO}]_{0}$ and $\left[\mathrm{O}_{3}\right]_{0}$ are the concentrations of $\mathrm{NO}$ and $\mathrm{O}_{3}$ at the beginning of the experiment and $[\mathrm{NO}]_{\text {final }},\left[\mathrm{O}_{3}\right]_{\text {final }}$ are those at the end. $\Delta\left(\left[\mathrm{O}_{3}\right]-[\mathrm{NO}]\right)$ represents the amounts of $\mathrm{NO}$ oxidized and $\mathrm{O}_{3}$ formed in the experiments, and also gives an indication of the biases in simulating $\mathrm{O}_{3}$ formation. In the four experiments, the prediction biases of $\Delta\left(\left[\mathrm{O}_{3}\right]-[\mathrm{NO}]\right)$ have been calculated to vary from -2.2 to $23.7 \%$ at the end of the experiments, which are within the values of $\pm 25 \%$ reported by Carter et al. (2005) when simulating VOC- $\mathrm{NO}_{\mathrm{x}}$ systems. The model results mentioned above illustrate that the GIG-CAS smog chamber can provide valuable data for mechanism evaluation.

\section{$3.8 \quad \alpha$-pinene ozonolysis SOA yield}

A series of experiments of $\alpha$-pinene ozonolysis in the dark were carried out to evaluate the chamber facility in studying SOA formation chemistry. This reaction has been widely studied and numerous data are readily found in the literature (Hoffmann et al., 1997; Griffin et al., 1999; Cocker et al., 2001b; Saathoff et al., 2009; Wang et al., 2011). Methods developed by Pankow (1994a, b) and Odum et al. (1996) are used to analyze the data. Briefly, SOA yield, $Y$, is defined as follows:
$Y=\frac{\Delta M_{0}}{\Delta \mathrm{ROG}}$

where $\Delta R O G$ is the mass concentration of reactive organic gas (ROG) reacted and $\Delta M_{0}$ is the total mass concentration of organic aerosols formed. $Y$ is a function of $M_{0}$ and the relation is described as

$Y=M_{0} \sum\left(\frac{\alpha_{i} K_{\mathrm{om}, i}}{1+K_{\mathrm{om}, i} M_{0}}\right)$,

where $K_{\mathrm{om}, i}$ and $\alpha_{i}$ are the mass-based absorption equilibrium partitioning coefficient and stoichiometric coefficient of product $i$, respectively, and $M_{0}$ is the total mass concentration of organic material. Odum et al. (1996) found that a two-product model could fit the yield data well if appropriate values for $\alpha_{1}, \alpha_{2}, K_{\mathrm{om}, 1}, K_{\mathrm{om}, 2}$ were chosen.

Five experiments of dark ozonolysis of $\alpha$-pinene were carried out under dry conditions near $295 \mathrm{~K}$ in the absence of $\mathrm{OH}$ scavenger and seed particles. The initial experimental conditions and results are listed in Table 6. Initial mixing ratios of $\alpha$-pinene varied from 13 to $87 \mathrm{ppb}$. An aerosol density of $1 \mathrm{~g} \mathrm{~cm}^{-3}$ was assumed to convert the volume concentration into the mass concentration for the calculation of aerosol yields. This assumed aerosol density is lower than that of $1.3 \mathrm{~g} \mathrm{~cm}^{-3}$ by Bahreini et al. (2005) or Alfarra et al. (2006) for $\alpha$-pinene SOA. However, Wirtz and MartinReviejo (2003) and Wang et al. (2011) both adopted a value 


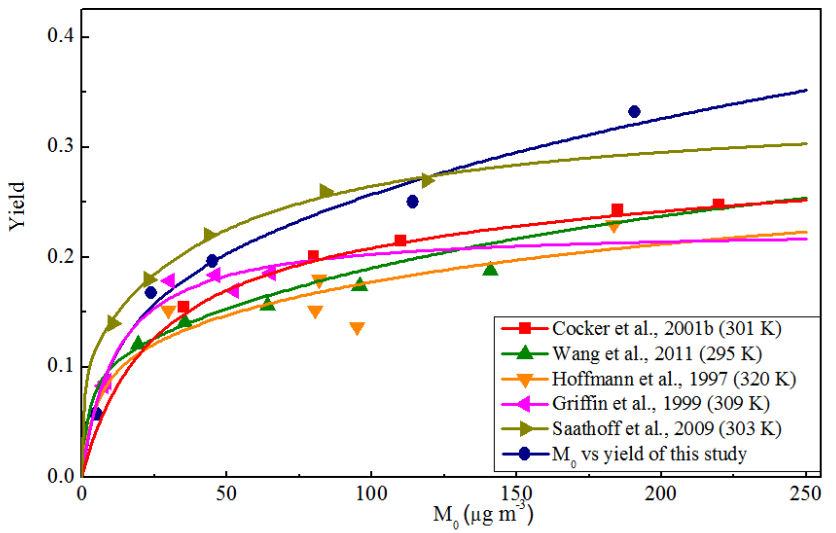

Fig. 7. Comparison of yield data obtained for $\alpha$-pinene ozonolysis experiments in GIG-CAS chamber with other chamber facilities. All experiments are carried out under dry condition. Blue line is the best fit two-product model for the data set of GIG-CAS.

of $1.0 \mathrm{~g} \mathrm{~cm}^{-3}$. Here we used the unit density for all the experiments when comparing our results with those from previous studies. Particles wall losses have to be accounted for to accurately quantify the SOA formation. The approach involving measuring the size-dependent wall loss rate of dry inert ammonium sulfate particles is not suitable for experiments in which nucleation occurs (Keywood et al., 2004). Here, we use the same method as Pathak et al. (2007) in that we calculate the total mass wall loss rate and apply this rate to the entire experiment. Comparison of yield data of this work and previous studies (Hoffmann et al., 1997; Griffin et al., 1999; Cocker et al., 2001b; Saathoff et al., 2009; Wang et al., 2011) is shown in Fig. 7. Only the yields obtained for the dark ozonolysis of $\alpha$-pinene under dry conditions in the absence of $\mathrm{OH}$ scavenger and seed particles were considered. The two-product model gives a good fit for the yield data obtained in this work. The appropriate values for $\alpha_{1}, \alpha_{2}$, $K_{\mathrm{om}, 1}$ and $K_{\mathrm{om}, 2}$ are $0.189,0.486,0.0958$ and 0.00218 , respectively. Only the data of Saathoff et al. (2009) are slightly higher than the yield curve obtained in this work, probably owing to their assumed aerosol density of $1.25 \mathrm{~g} \mathrm{~cm}^{-3}$ when calculating aerosol mass concentrations. Most yield data of other studies are lower than the yields in this work for the same amount of SOA generated. This may be attributed to the influence of temperature because SOA yield is demonstrated to inversely depend on temperature (Saathoff et al., 2009).

\section{Conclusions}

We have built the largest indoor smog chamber in China, and initial characterization experiments described in this paper demonstrate that our GIG-CAS smog chamber facility can be used to provide valuable data for gas-phase chemistry and secondary aerosol formation. The chamber has been shown to exhibit good temperature homogeneity and mixing efficiency. Observed relative lower wall loss rates of gas species and particles reflect the long lifetime of these species and small wall effects. Results of propene- $\mathrm{NO}_{\mathrm{x}}$-air irradiation experiments illustrate its utility for evaluating gas-phase chemical mechanisms. Furthermore, the good reproducibility of $\alpha$-pinene ozonolysis experiments and the good agreement with previous studies demonstrate its ability for the study of secondary organic aerosol formation.

Acknowledgements. This work was supported by the Chinese Academy of Sciences (YZ200918 and XDB05010200), the Natural Science Foundation of China (41025012/U0833003) and the Guangzhou Institute of Geochemistry (GIGCAS 135 project Y234161001). We would like to express our sincere gratitude to John Seinfeld at the California Institute of Technology as well as Paul Ziemann and David Cooker at the University of California, Riverside, for giving us good advice when we visited their chambers and consulted them about the design of our smog chamber.

Edited by: Y. Iinuma

\section{References}

Aiken, A. C., DeCarlo, P. F., and Jimenez, J. L.: Elemental Analysis of Organic Species with Electron Ionization HighResolution Mass Spectrometry, Anal. Chem., 79, 8350-8358, doi:10.1021/ac071150w, 2007.

Aiken, A. C., DeCarlo, P. F., Kroll, J. H., Worsnop, D. R., Huffman, J. A., Docherty, K. S., Ulbrich, I. M., Mohr, C., Kimmel, J. R., Sueper, D., Sun, Y., Zhang, Q., Trimborn, A., Northway, M., Ziemann, P. J., Canagaratna, M. R., Onasch, T. B., Alfarra, M. R., Prevot, A. S. H., Dommen, J., Duplissy, J., Metzger, A., Baltensperger, U., and Jimenez, J. L.: O/C and OM/OC Ratios of Primary, Secondary, and Ambient Organic Aerosols with HighResolution Time-of-Flight Aerosol Mass Spectrometry, Environ. Sci. Technol., 42, 4478-4485, doi:10.1021/es703009q, 2008.

Akimoto, H., Hoshino, M., Inoue, G., Sakamaki, F., Washida, N., and Okuda, M.: Design and characterization of the evacuable and bakable photochemical smog chamber, Environ. Sci. Technol., 13, 471-475, doi:10.1021/es60152a014, 1979.

Alfarra, M. R., Paulsen, D., Gysel, M., Garforth, A. A., Dommen, J., Prévôt, A. S. H., Worsnop, D. R., Baltensperger, U., and Coe, H.: A mass spectrometric study of secondary organic aerosols formed from the photooxidation of anthropogenic and biogenic precursors in a reaction chamber, Atmos. Chem. Phys., 6, 52795293, doi:10.5194/acp-6-5279-2006, 2006.

Atkinson, R., Baulch, D. L., Cox, R. A., Crowley, J. N., Hampson, R. F., Hynes, R. G., Jenkin, M. E., Rossi, M. J., and Troe, J.: Evaluated kinetic and photochemical data for atmospheric chemistry: Volume $\mathrm{I}-$ gas phase reactions of $\mathrm{O}_{\mathrm{x}}, \mathrm{HO}_{\mathrm{x}}, \mathrm{NO}_{\mathrm{x}}$ and $\mathrm{SO}_{\mathrm{x}}$ species, Atmos. Chem. Phys., 4, 1461-1738, doi:10.5194/acp-41461-2004, 2004.

Bahreini, R., Keywood, M. D., Ng, N. L., Varutbangkul, V., Gao, S., Flagan, R. C., Seinfeld, J. H., Worsnop, D. R., and Jimenez, J. L.: Measurements of Secondary Organic Aerosol from Oxidation of Cycloalkenes, Terpenes, and m-Xylene Using an Aerodyne 
Aerosol Mass Spectrometer, Environ. Sci. Technol., 39, 56745688, doi:10.1021/es048061a, 2005.

Barnes, I., Becker, K. H., Carlier, P., and Mouvier, G.: FTIR study of the DMS/NO $/ \mathrm{I}_{2} / \mathrm{N}_{2}$ photolysis system: The reaction of IO radicals with DMS, Int. J. Chem. Kinet., 19, 489-501, 1987.

Bloss, C., Wagner, V., Jenkin, M. E., Volkamer, R., Bloss, W. J., Lee, J. D., Heard, D. E., Wirtz, K., Martin-Reviejo, M., Rea, G., Wenger, J. C., and Pilling, M. J.: Development of a detailed chemical mechanism (MCMv3.1) for the atmospheric oxidation of aromatic hydrocarbons, Atmos. Chem. Phys., 5, 641-664, doi:10.5194/acp-5-641-2005, 2005.

Carter, W. P. L.: Documentation of the SAPRC-99 chemical mechanism for VOC reactivity assessment, Report to the California Air Resources Board, Contracts 92-329 and 95-308, 8 May, 2000.

Carter, W. P. L. and Lurmann, F. W.: Evaluation of a detailed gas-phase atmospheric reaction mechanism using environmental chamber data, Atmos. Environ. A, 25, 2771-2806, doi:10.1016/0960-1686(91)90206-M, 1991.

Carter, W. P. L., Atkinson, R., Winer, A. M., and Pitts, J. N.: Experimental investigation of chamber-dependent radical sources, Int. J. Chem. Kinet., 14, 1071-1103, doi:10.1002/kin.550141003, 1982.

Carter, W. P. L., Cocker, D. R., Fitz, D. R., Malkina, I. L., Bumiller, K., Sauer, C. G., Pisano, J. T., Bufalino, C., and Song, C.: A new environmental chamber for evaluation of gas-phase chemical mechanisms and secondary aerosol formation, Atmos. Environ., 39, 7768-7788, doi:10.1016/j.atmosenv.2005.08.040, 2005.

Chan, C. K. and Yao, X. H.: Air pollution in mega cities in China, Atmos. Environ., 42, 1-42, 2008.

Cocker, D. R., Flagan, R. C., and Seinfeld, J. H.: State-of-theart chamber facility for studying atmospheric aerosol chemistry, Environ. Sci. Technol., 35, 2594-2601, doi:10.1021/Es0019169, 2001a.

Cocker, D. R., Clegg, S. L., Flagan, R. C., and Seinfeld, J. H.: The effect of water on gas-particle partitioning of secondary organic aerosol. Part I: $\alpha$-pinene/ozone system, Atmos. Environ., 35, 6049-6072, doi:10.1016/S1352-2310(01)00404-6, 2001b.

DeCarlo, P. F., Kimmel, J. R., Trimborn, A., Northway, M. J., Jayne, J. T., Aiken, A. C., Gonin, M., Fuhrer, K., Horvath, T., Docherty, K. S., Worsnop, D. R., and Jimenez, J. L.: Field-Deployable, High-Resolution, Time-of-Flight Aerosol Mass Spectrometer, Anal. Chem., 78, 8281-8289, doi:10.1021/ac061249n, 2006.

Dodge, M. C.: Chemical oxidant mechanisms for air quality modeling: critical review, Atmos. Environ., 34, 2103-2130, doi:10.1016/S1352-2310(99)00461-6, 2000.

Donahue, N. M., Henry, K. M., Mentel, T. F., Kiendler-Scharr, A., Spindler, C., Bohn, B., Brauers, T., Dorn, H. P., Fuchs, H., Tillmann, R., Wahner, A., Saathoff, H., Naumann, K.-H., Möhler, O., Leisner, T., Müller, L., Reinnig, M.-C., Hoffmann, T., Salo, K., Hallquist, M., Frosch, M., Bilde, M., Tritscher, T., Barmet, P., Praplan, A. P., DeCarlo, P. F., Dommen, J., Prévôt, A. S. H., and Baltensperger, U.: Aging of biogenic secondary organic aerosol via gas-phase $\mathrm{OH}$ radical reactions, P. Natl. Acad. Sci., 109, 13503-13508, doi:10.1073/pnas.1115186109, 2012.

Doussin, J. F., Ritz, D., Durand-Jolibois, R., Monod, A., and Carlier, P.: Design of an environmental chamber for the study of atmospheric chemistry: New developments in the analytical device, Analusis, 25, 236-242, 1997.
Griffin, R. J., Cocker III, D. R., Flagan, R. C., and Seinfeld, J. H.: Organic aerosol formation from the oxidation of biogenic hydrocarbons, J. Geophys. Res., 104, 3555-3567, doi:10.1029/1998jd100049, 1999.

Grosjean, D.: Wall loss of gaseous pollutants in outdoor Teflon chambers, Environ. Sci. Technol., 19, 1059-1065, doi:10.1021/es00141a006, 1985.

Hess, G. D., Carnovale, F., Cope, M. E., and Johnson, G. M.: The evaluation of some photochemical smog reaction mechanisms I. Temperature and initial composition effects, Atmos. Environ. A, 26, 625-641, doi:10.1016/0960-1686(92)90174-J, 1992.

Hoffmann, T., Odum, J. R., Bowman, F., Collins, D., Klockow, D., Flagan, R. C., and Seinfeld, J. H.: Formation of organic aerosols from the oxidation of biogenic hydrocarbons, J. Atmos. Chem., 26, 189-222, 1997.

Hynes, R. G., Angove, D. E., Saunders, S. M., Haverd, V., and Azzi, M.: Evaluation of two MCM v3.1 alkene mechanisms using indoor environmental chamber data, Atmos. Environ., 39, 72517262, 2005.

Jayne, J. T., Leard, D. C., Zhang, X., Davidovits, P., Smith, K. A., Kolb, C. E., and Worsnop, D. R.: Development of an Aerosol Mass Spectrometer for Size and Composition Analysis of Submicron Particles, Aerosol. Sci. Tech., 33, 49-70, doi:10.1080/027868200410840, 2000.

Jeffries, H. E., Kamens, R. M., Sexton, K. G., and Gerhardt, A. A.: Outdoor smog chamber experiments to test photochemical models, EPA-600/3-82-016a, April, 1982.

Jeffries, H. E., Sexton, K. G., Kamens, R. M., and Holleman, M. S.: Outdoor smog chamber experiments to test photochemical models: phase II, Final Report, EPA-600/3-85-029, 1985.

Johnson, D., Jenkin, M. E., Wirtz, K., and Martin-Reviejo, M.: Simulating the Formation of Secondary Organic Aerosol from the Photooxidation of Toluene, Environ. Chem., 1, 150-165, doi:10.1071/EN04069, 2004.

Jordan, A., Haidacher, S., Hanel, G., Hartungen, E., Mark, L., Seehauser, H., Schottkowsky, R., Sulzer, P., and Mark, T. D.: A high resolution and high sensitivity proton-transfer-reaction time-offlight mass spectrometer (PTR-TOF-MS), Int. J. Mass Spectrom., 286, 122-128, 2009.

Keywood, M. D., Varutbangkul, V., Bahreini, R., Flagan, R. C., and Seinfeld, J. H.: Secondary Organic Aerosol Formation from the Ozonolysis of Cycloalkenes and Related Compounds, Environ. Sci. Technol., 38, 4157-4164, doi:10.1021/es035363o, 2004.

Leone, J. A., Flagan, R. C., Grosjean, D., and Seinfeld, J. H.: An outdoor smog chamber and modeling study of toluene - $\mathrm{NO}_{\mathrm{x}}$ photooxidation, Int. J. Chem. Kinet., 17, 177-216, doi:10.1002/kin.550170206, 1985.

Lindinger, W., Hansel, A., and Jordan, A.: On-line monitoring of volatile organic compounds at pptv levels by means of protontransfer-reaction mass spectrometry (PTR-MS) medical applications, food control and environmental research, Int. J. Mass Spectrom., 173, 191-241, 1998.

Martín-Reviejo, M. and Wirtz, K.: Is Benzene a Precursor for Secondary Organic Aerosol?, Environ. Sci. Technol., 39, 10451054, doi:10.1021/es049802a, 2005.

Metzger, A., Dommen, J., Gaeggeler, K., Duplissy, J., Prevot, A. S. H., Kleffmann, J., Elshorbany, Y., Wisthaler, A., and Baltensperger, U.: Evaluation of 1,3,5 trimethylbenzene degradation in the detailed tropospheric chemistry mechanism, MCMv3.1, 
using environmental chamber data, Atmos. Chem. Phys., 8, 6453-6468, doi:10.5194/acp-8-6453-2008, 2008.

Odum, J. R., Hoffmann, T., Bowman, F., Collins, D., Flagan, R. C., and Seinfeld, J. H.: Gas/Particle Partitioning and Secondary Organic Aerosol Yields, Environ. Sci. Technol., 30, 2580-2585, doi:10.1021/es950943+, 1996.

Odum, J. R., Jungkamp, T. P. W., Griffin, R. J., Forstner, H. J. L., Flagan, R. C., and Seinfeld, J. H.: Aromatics, Reformulated Gasoline, and Atmospheric Organic Aerosol Formation, Environ. Sci. Technol., 31, 1890-1897, doi:10.1021/es9605351, 1997.

Pandis, S. N., Paulson, S. E., Seinfeld, J. H., and Flagan, R. C.: Aerosol formation in the photooxidation of isoprene and $\beta$ pinene, Atmos. Environ. A, 25, 997-1008, 1991.

Pankow, J. F.: An Absorption-Model of Gas-Particle Partitioning of Organic-Compounds in the Atmosphere, Atmos. Environ., 28, 185-188, 1994a.

Pankow, J. F.: An Absorption-Model of the Gas Aerosol Partitioning Involved in the Formation of Secondary Organic Aerosol, Atmos. Environ., 28, 189-193, 1994b.

Pathak, R. K., Stanier, C. O., Donahue, N. M., and Pandis, S. N.: Ozonolysis of alpha-pinene at atmospherically relevant concentrations: Temperature dependence of aerosol mass fractions (yields), J. Geophys. Res.-Atmos., 112, D03201, doi:10.1029/2006JD007436, 2007.

Paulsen, D., Dommen, J., Kalberer, M., Prévôt, A. S. H., Richter, R., Sax, M., Steinbacher, M., Weingartner, E., and Baltensperger, U.: Secondary Organic Aerosol Formation by Irradiation of 1,3,5Trimethylbenzene $-\mathrm{NO}_{\mathrm{x}}-\mathrm{H}_{2} \mathrm{O}$ in a New Reaction Chamber for Atmospheric Chemistry and Physics, Environ. Sci. Technol., 39, 2668-2678, doi:10.1021/es0489137, 2005.

Pinho, P. G., Pio, C. A., Carter, W. P. L., and Jenkin, M. E.: Evaluation of alkene degradation in the detailed tropospheric chemistry mechanism, MCM v3, using environmental chamber data, J. Atmos. Chem., 55, 55-79, doi:10.1007/s10874-006-9025-y, 2006.

Ren, K., Li, J., Wang, W., and Zhang, H.: Investigation on experiment system for modeling of photochemical smog, Acta ScientiaeCircumatantiae, 25, 1431-1435, 2005.

Rollins, A. W., Kiendler-Scharr, A., Fry, J. L., Brauers, T., Brown, S. S., Dorn, H.-P., Dubé, W. P., Fuchs, H., Mensah, A., Mentel, T. F., Rohrer, F., Tillmann, R., Wegener, R., Wooldridge, P. J., and Cohen, R. C.: Isoprene oxidation by nitrate radical: alkyl nitrate and secondary organic aerosol yields, Atmos. Chem. Phys., 9, 6685-6703, doi:10.5194/acp-9-6685-2009, 2009.

Saathoff, H., Moehler, O., Schurath, U., Kamm, S., Dippel, B., and Mihelcic, D.: The AIDA soot aerosol characterisation campaign 1999, J. Aerosol Sci., 34, 1277-1296, doi:10.1016/S00218502(03)00363-X, 2003.

Saathoff, H., Naumann, K.-H., Möhler, O., Jonsson, Å. M., Hallquist, M., Kiendler-Scharr, A., Mentel, Th. F., Tillmann, R., and Schurath, U.: Temperature dependence of yields of secondary organic aerosols from the ozonolysis of $\alpha$-pinene and limonene, Atmos. Chem. Phys., 9, 1551-1577, doi:10.5194/acp-9-15512009, 2009.

Saunders, S. M., Jenkin, M. E., Derwent, R. G., and Pilling, M. J.: Protocol for the development of the Master Chemical Mechanism, MCM v3 (Part A): tropospheric degradation of nonaromatic volatile organic compounds, Atmos. Chem. Phys., 3, 161-180, doi:10.5194/acp-3-161-2003, 2003.
Simonaitis, R., Meagher, J. F., and Bailey, E. M.: Evaluation of the condensed carbon bond (CB-IV) mechanism against smog chamber data at low VOC and $\mathrm{NO}_{\mathrm{x}}$ concentrations, Atmos. Environ., 31, 27-43, doi:10.1016/S1352-2310(96)00155-0, 1997.

Stern, J. E., Flagan, R. C., Grosjean, D., and Seinfeld, J. H.: Aerosol formation and growth in atmospheric aromatic hydrocarbon photooxidation, Environ. Sci. Technol., 21, 1224-1231, doi:10.1021/es00165a011, 1987.

Takekawa, H., Minoura, H., and Yamazaki, S.: Temperature dependence of secondary organic aerosol formation by photo-oxidation of hydrocarbons, Atmos. Environ., 37, 3413-3424, 2003.

Tang, J. H., Wang, X. M., Feng, Y. L., Sheng, G. Y., and Fu, J. M.: Determination of C-1 similar to C-10 carbonyls in the atmosphere, Chinese J. Anal. Chem., 31, 1468-1472, 2003.

Tobias, H. J. and Ziemann, P. J.: Compound identification in organic aerosols using temperature programmed thermal desorption particle beam mass spectrometry, Anal. Chem., 71, 34283435, 1999.

Vlasenko, A., Macdonald, A .M., Sjostedt, S. J., and Abbatt, J. P. D.: Formaldehyde measurements by Proton transfer reaction - Mass Spectrometry (PTR-MS): correction for humidity effects, Atmos. Meas. Tech., 3, 1055-1062, doi:10.5194/amt-3-1055-2010, 2010.

Wang, J., Doussin, J. F., Perrier, S., Perraudin, E., Katrib, Y., Pangui, E., and Picquet-Varrault, B.: Design of a new multi-phase experimental simulation chamber for atmospheric photosmog, aerosol and cloud chemistry research, Atmos. Meas. Tech., 4, 2465-2494, doi:10.5194/amt-4-2465-2011, 2011.

Wang, W., Xie, Y., Lin, Z., and Wang, H.: Study on reaction rate constants of $\mathrm{CH}_{4}$ and its lifetime, China Environ. Sci., 15, 258$261,1995$.

Wang, X. M. and Wu, T.:Release of isoprene and monoterpenes during the aerobic decomposition of orange wastes from laboratory incubation experiments, Environ. Sci. Technol., 42, 3265-3270, 2008.

Wirtz, K. and Martin-Reviejo, M.: Density of secondary organic aerosols, J. Aerosol Sci., 34, S223-S224, 2003.

Wu, S., Lü, Z., Hao, J., Zhao, Z., Li, J., Takekawa, H., Minoura, H., and Yasuda, A.: Construction and characterization of an atmospheric simulation smog chamber, Adv. Atmos. Sci., 24, 250 258, doi:10.1007/s00376-007-0250-3, 2007.

Xu, Y., Jia, L., Ge, M., Du, L., Wang, G., and Wang, D.: A kinetic study of the reaction of ozone with ethylene in a smog chamber under atmospheric conditions, Chinese Sci. Bull., 51, 28392843, doi:10.1007/s11434-006-2180-3, 2006.

Zádor, J., Wagner, V., Wirtz, K., and Pilling, M. J.: Quantitative assessment of uncertainties for a model of tropospheric ethene oxidation using the European Photoreactor (EUPHORE), Atmos. Environ., 39, 2805-2817, doi:10.1016/j.atmosenv.2004.06.052, 2005.

Zhang, Q., He, K. B., and Huo, H.: Clean China's air, Nature, 484, 161-162, 2012.

Zhang, Y. L., Guo, H., Wang, X. M., Simpson, I. J., Barletta, B., Blake, D. R., Meinardi, S., Rowland, F. S., Cheng, H. R., Saunders, S. M., and Lam, S. H. M.: Emission patterns and spatiotemporal variations of halocarbons in the Pearl River Delta region, southern China, J. Geophys. Res.-Atmos., 115, D15309, doi:10.1029/2009JD013726, 2010. 
Zhang, Y. L., Wang, X. M., Blake, D. R., Li, L. F., Zhang, Z., Wang, S. Y., Guo, H., Lee, F. S. C., Gao, B., Chan, L. Y., Wu, D., and Rowland, F. S.:Aromatic hydrocarbons as ozone precursors before and after outbreak of the 2008 financial crisis in the Pearl River Delta region, south China, J. Geophys. Res.-Atmos., 117, D15306, doi:10.1029/2011JD017356, 2012.
Zhang, Y., Wang, X., Zhang, Z., Lü, S., Shao, M., Lee, F. S. C., and Yu, J.: Species profiles and normalized reactivity of volatile organic compounds from gasoline evaporation in China, Atmos. Environ., 79, 110-118, doi:10.1016/j.atmosenv.2013.06.029, 2013. 